\title{
Production of tifton 85 hay overseeded with white oats or ryegrass
}

\author{
Marcela Abbado Neres ${ }^{1}$, Deise Dalazen Castagnara ${ }^{2}$, Eduardo Eustáquio Mesquita ${ }^{1}$, Clóves \\ Cabreira Jobim ${ }^{3}$, Tamara Taís Três ${ }^{4}$, Paulo Sérgio Rabello Oliveira ${ }^{1}$, Ana Alix Mendes de \\ Almeida Oliveira ${ }^{1}$
}

\footnotetext{
1 Universidade Estadual do Oeste do Paraná. Rua Pernambuco, 1777, Centro, Marechal Cândido Rondon, PR, 85960-000.

2 Doutoranda em Produção Vegetal Universidade Estadual do Oeste do Paraná - Unioeste, PR.

3 Universidade Estadual de Maringá - UEM. Av. Colombo, 1790, Jardim Universitário, Maringá, PR, 87020900.

${ }^{4}$ Mestranda em Pastagem e Forragicultura - Universidade Estadual do Maringá - UEM.
}

\begin{abstract}
The objective of this experiment was to estimate the curve of dehydration, chemical composition and in vitro dry matter digestibility (IVDMD) and crude protein digestibility (IVCPD) of tifton 85 hay, produced single or overseeded with ryegrass or white oat IPR 126. The experimental design was in randomized blocks, in a $3 \times 10$ factorial arrangement, with three cropping systems and ten evaluation times (0, 4, 8, 24, 28, 32, 48, 52 and 56 and 71 hours after harvest) during the dehydration process. For chemical composition and in vitro DM and CP digestibility, the experimental design was in randomized blocks with three cropping systems and three evaluation times (before cutting, before baling and 100 days after of storage). It was found that tifton 85 intercropped with white oat kept its higher nutritional value after storage, with $19.78 \%$ crude protein and $70.03 \%$ of in vitro dry matter digestibility. The participation of white oat in tifton 85 area was $57.04 \%$ and for ryegrass, it was $38.52 \%$, but the dry matter yield of single tifton 85 was higher than other intercrops. Thus, it is recommended an oversowing of winter annual species on Tifton 85, without moisture restriction, because of the benefits obtained in the hay nutritional value.
\end{abstract}

Key Words: cool-winter annual hay, crude protein, dehydratation, forage conservation, in vitro dry matter digestibility

\section{Introduction}

Forage production maintained as hay is essential for the production of dairy cows and the advantage of an available hay in diet is its nutritional value, effectiveness of its fiber, which promotes physical activity on gastrointestinal tract stimulating rumination and maintenance of milk fat percentage, which contraindicates, in these cases, finely chopped hays (Mertens, 1994).

At the beginning of their growth, rumen of calves needs hay supply for their good development. Another advantage of hay is its easy conservation, being dehydrated, it makes handling and conservation and it can be used continuously or in critical periods of pastures production, depending on the production system.

Muck \& Shinners (2001) highlighted the need for studies for understanding the processes which affects hay quality during production, storage and health aspects. When Tifton 85 is managed as hay, it stands out a high quality, high proportion of leaves and resistance to cuts close to soil (Carnevalli et al, 2001).

The use of oversowing with annual species from mild weather in areas cropped with Tifton 85 during the winter is as an alternative to maximize the area use, thus improving the quantity and quality of hay produced because of the low production and quality of Tifton 85 in these months. Oversowing term is used to describe the practice of establishing hay crops in annual pastures with perennial species as grass or areas for hay production, without destroying the existing vegetation.

White oats and ryegrass are considered as available species for oversowing in areas cropped with tifton 85 inasmuch as they show high nutritional value and fast growth, resulting in an increased production and period of field use of hay production.

Therefore, the oversowing of winter species in areas cultivated with perennial species of tropical climate for hay production is one option to be considered to increase production, quality and its seasonal distribution. On the other hand, the intercrop of winter annual species with Tifton 85 should consider that dehydration rates may vary due to structural characteristics of white oat and ryegrass, such as the stem thickness, leaf/stem ratio, interfering on drying time and final dry matter percentage. These responses may extend to hay quality after storage. So, the objective of this work was to evaluate dehydration rates, chemical 
composition and in vitro dry matter digestibility and crude protein of Tifton 85, single or overseeded with white oats and ryegrass.

\section{Material and Methods}

The experiment was carried out under field conditions at the Experimental Farm Antônio Carlos dos Santos Pessoa, which belongs to Universidade Estadual do Oeste do Paraná, campus Marechal Candido Rondon, at 24 33' 40', S latitude, $54^{\circ} 04^{\prime} 12^{\prime \prime}$ ' W longitude and $420 \mathrm{~m}$ altitude. The local weather is Cfa classified according to Koppen, subtropical with well distributed rainfalls throughout the year and hot summers. The average temperatures of the coldest quarter range from 17 to $18^{\circ} \mathrm{C}$, at the hotest quarter, they range from 28 to $29^{\circ} \mathrm{C}$, whereas the annual average temperature is between 22 and $23^{\circ} \mathrm{C}$. The total average annual rainfall for the region varies from 1,600 to $1,800 \mathrm{~mm}$, with the most humid quarter showing totals ranging from 400 to $500 \mathrm{~mm}$ (IAPAR, 2006). Climatic conditions were favorable during plants development (Figure 1) and drying (Table 1).

The soil is classified as Eutroferric Red Latosol with the following chemical characteristics: water $\mathrm{pH}=5.70$; $\mathrm{P}$ $($ Mehlich $)=10.78 \mathrm{mg} / \mathrm{dm}^{3} ; \mathrm{K}($ Mehlich $)=0.13 \mathrm{cmol}_{\mathrm{C}} / \mathrm{dm}^{3}$;

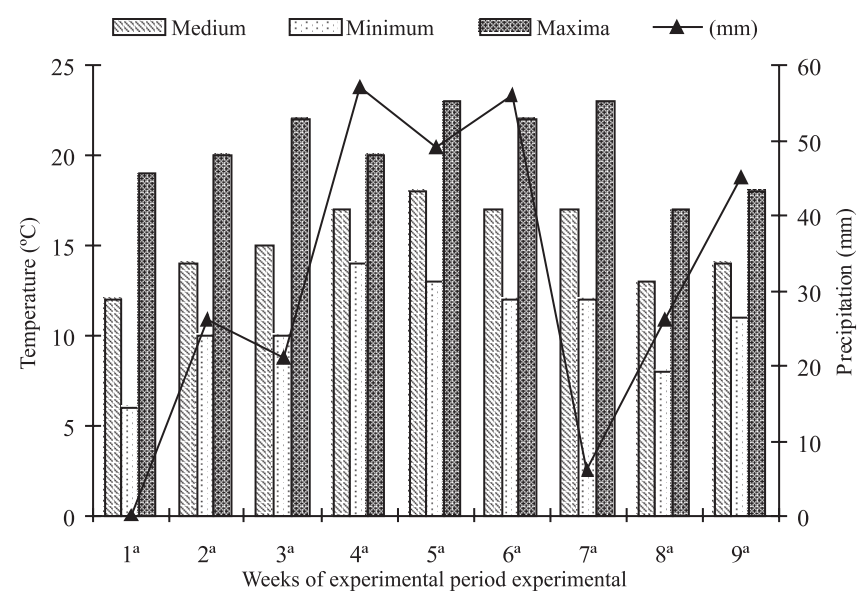

Figure 1 - Weather data during the experimental period. Marechal Candido Rondon, June-July 2009.
$\mathrm{Ca}^{2}+\left(\mathrm{KCl} 1 \mathrm{~mol} \mathrm{~L}^{-1}\right)=5.21 \mathrm{cmol}_{\mathrm{C}} / \mathrm{dm}^{3} ; \mathrm{Mg}^{2+}(\mathrm{KCl} 1 \mathrm{~mol} / \mathrm{L})=$ $0.91 \mathrm{cmol}_{\mathrm{c}} / \mathrm{dm}^{3} ; \mathrm{Al}^{3+}(\mathrm{KCl} 1 \mathrm{~mol} / \mathrm{L})=0.00 \mathrm{cmol}_{\mathrm{c}} / \mathrm{dm}^{3}$; $\mathrm{H}+\mathrm{Al}$ (calcium acetate $0.5 \mathrm{~mol} / \mathrm{L}$ ) $=4.14 \mathrm{cmol}_{\mathrm{c}} / \mathrm{dm}^{3}$; $\mathrm{SB}=6.15 \mathrm{cmol}_{\mathrm{C}} / \mathrm{dm}^{3} ; \mathrm{CTC}=\mathrm{cmol}_{\mathrm{C}} / \mathrm{dm}^{3} \mathrm{~V} 10.29=59.77 \%$, organic matter (Method Boyocus) $=30.07 \mathrm{~g} / \mathrm{dm}^{3}$ and clay $=65 \%$. In January, 2009, $100 \mathrm{~kg} \mathrm{P}_{2} \mathrm{O}_{5}$ per hectare were used as simple superphosphate and $250 \mathrm{~kg} / \mathrm{ha}$ of NPK formula 8-20-20 were used at sowing of winter crops.

The experiment was established in 1.0-ha area and treatments were as follows: Tifton 85 hay, Tifton 85 hay intercropped with white oats and Tifton 85 hay intercropped with ryegrass. To determine the dehydration curve, samples were collected at 0 (at cutting), 4, 8, 24, 28, 32, 48, 52, 56 and 72 hours after cut, according to a completly randomized experimental design in $3 \times 10$ factorial arrangement (three cropping systems) and ten collection times, with five replications. For chemical composition and chemical in vitro dry matter digestibility and crude protein, the experimental design was completely randomized, in a $3 \times 3$ factorial arrangement, with three cropping systems and three evaluation periods (before cutting, before baling and after 100 days of storage), with five replications.

Planting of winter white oat (Avena sativa cv. IPR 126) and ryegrass (Lolium multiflorum Lam.) was at the beginning of June 2009, right after the cutting of tifton 85 for haymaking. A mechanized seed drill for direct seeding was coupled to the tractor (it was not performed the drying of tifton 85 plants) in $0.20 \mathrm{~m}$ of rows and with $70 \mathrm{~kg} / \mathrm{ha}$ of seeds for each species.

There were 55 days for development period and during this period, pests and diseases occurred in the evaluated species. The cutting of hay in the experimental area was carried out on September $29^{\text {th }} 2009$ at 9 a.m. by using a mower set at a $5 \mathrm{~cm}$ - height from the ground. The material was cut and spread in the field for drying. The turning of treatments was performed at 6 and 26 hours after cutting.

For determination of dry matter production, sample collections were done before passage of a $1-\mathrm{m}^{2}$ square mower randomly placed in the different treatments. Samples were wrapped up in paper bags, weighed and oven-dried ( $55^{\circ} \mathrm{C}, 72$ hours). Collection of samples to determine drying curves for different drying methods were performed at 0

Table 1 - Climate data on the dates for cutting and drying of Tifton 85 plants (Marechal Candido Rondon, June-July 2009)

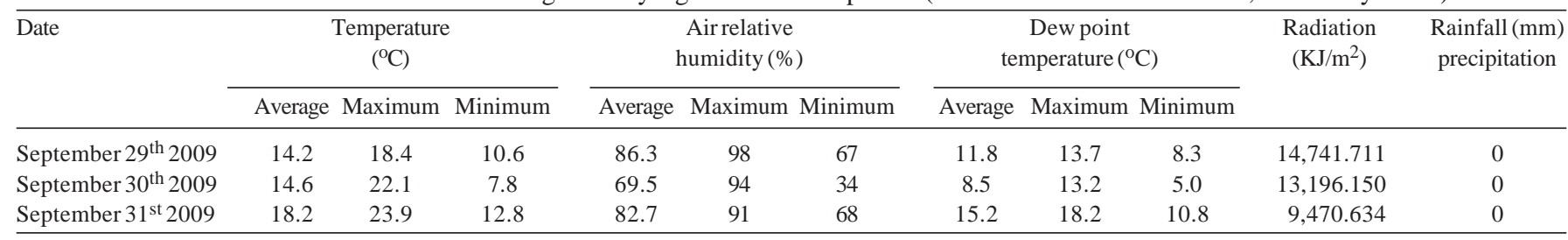


(cutting moment), 4, 8, 24, 28, 32, 48, 52, 56 and 71 hours after cutting. The samples were collected by following the same methodology to determine dry matter production. According to the samples collected in overseeded areas, sub-samples were separed to determine dry matter yield and dry matter percentage of isolated species.

After 71 hours of drying, hays were mechanically baled in 12-kg average weight rectangular bales. Bales were stored in warehouse under the same conditions of temperature, light and humidity, protected from rain and sunshine.

The determination of leaf/stem ratio, performed after plants cutting, was according to a collection of $50-\mathrm{g}$ sample per drying method. After collecting the material, stems and leaves of samples were separated and samples were placed in paper bags and dried at $55^{\circ} \mathrm{C}$ for 72 hours in a forced air ventilation oven. The leaf/stem ratio (L/S) was obtained by the ratio between dry weight of leaves and dry weight of stems.

Samples were collected at the harvesting season to determine chemical composition, before baling and 100 days after storage. The dried samples were ground in Willey type mill, 30-mesh sieve and stored in plastic bags, properly identified, to evaluate dry matter (DM) and crude protein (CP) according to AOAC (1990); neutral detergent fiber (NDF) and acid detergent fiber (ADF) according to Van Soest et al. (1991), neutral detergent insoluble protein (NDIP), acid detergent insoluble protein (ADIP), indigestible protein (IP), cellulose, hemicellulose, lignin and ash were estimated according to Silva \& Queiroz (2006).

In order to determine in vitro dry matter digestibility (IVDMD) and in vitro crude protein digestibility (IVCPD), it was used the technique described by Tilley \& Terry (1963) adapted to the Artificial Rumen as described by Holden (1999). The in vitro DM digestibility (IVDMD) and in vitro crude protein digestibility (IVCPD) were calculated as the difference between the incubated amount and residue after incubation.

Data were submitted to statistical analysis based on SAEG program (1997). The means of dry matter production, leaf/stem ratio, chemical composition, in vitro DM digestibility and in vitro CP digestibility were compared by using Tukey test at $5 \%$ probability. Data on dry matter content of the whole plant were submited to regression analysis by using the SAEG program (1997).

\section{Results and Discussion}

Single Tifton 85 dry matter yield was greater $(\mathrm{P}<0.05)$ thanTifton 85 overseeded with ryegrass or white oat
(Table 2), showing that Tifton 85 had grown during the prevailing climatic conditions in the experimental year. In the system Tifton $85+$ oat, production of single Tifton 85 was superior by $633.0 \mathrm{~kg} / \mathrm{ha}$ and in the system Tifton $85+$ ryegrass, this response was $553.0 \mathrm{~kg} / \mathrm{ha}$. The participation of white oats in Tifton 85 area was $57.04 \%$ and $38.52 \%$ for ryegrass; based on the results, hay produced in intercropping presented a better nutritional quality (Table 3 ).

This is caused partially because of the C3 photosynthetic cycle of these winter hay plants, which had higher proportion of leaves (Table 2) in relation to the C4 cycle grass plants. According to Moreira \& Reis (2007), annual winter grasses produced, under cutting conditions, aproximately from 3 to $6 \mathrm{t} / \mathrm{ha} /$ year DM, depending on soil fertility and moisture, and, in this work, this response was obtained with only one cut at production of $1,467.68 \mathrm{~kg} / \mathrm{ha}$ dry matter. White oat produced more than ryegrass plants because they are better adapted to higher temperatures than are ryegrass during winter and that was the climate condition observed during the evaluation months.

The leaf/stem ratio of single or intercropped Tifton 85 was around 1.63, which was different $(\mathrm{P}<0.05)$ from white oats and ryegrass which were 5.02 and 4.05 , respectively. In grazing system with beef heifers, Freitas et al. (2005) obtained leaf/stem ratio ranging from 0.32 to 2.08 in intercropped pasture of black oats and ryegrass, whereas Moreira and Reis (2007) obtained 0.94 in areas cropped only with Tifton 85. Three days after experimental area cutting, the white oats already presented a $3-\mathrm{cm}$ resprout, so, there is a chance on carrying out several cuts during the fall/winter.

After hay cutting, there was an increase on plants dry weight contents (Figures 2 and 3 ) according to the fastest initial losses of moisture since the stomata were kept open in the early hours; after the stomata close, moisture losses are slower because they occur through cuticle (Moser, 1995). In the early morning, after 24 hours of cutting, there was an increase in moisture of plants with results adjusted to the quadratic regression model (Table 2).

Andrade et al. (2006) also recorded some decline in DM contents in the early morning, when analyzing three cultivars of alfalfa versus time of dehydration. The authors obtained $83.4 \%$ as average DM in 73 hours of dehydration. The increase of moisture is due to dew at night. According to Rotz (1995), hay is hygroscopic, therefore, it has the ability to absorb or lose water to the environment, allowing the influence of relative humidity $(\mathrm{RH})$ on moisture content of the material exposed to the environment.

The moisture from the night was quickly lost in a few hours of sun. This confirms the observation performed by 
Calixto Jr. et al. (2007). From the cutting moment to 32 hours of drying, dehydration curves were differentiated (Figure 3), showing Tifton 85 with faster dehydration rate and intercrops with slower losses as result of higher levels of humidity at the cutting moment. The intercrops presented 20\% DM at the cutting moment, while Tifton 85 showed 35\% DM. But, in 71 hours of dehydration, single Tifton 85 and intercroppings reached the best DM for storage. This complies with a basic principle of haymaking that can be added into the conservation of hay nutritive value through rapid dehydration; according to Collins (1995), hay under drying periods exceeding 7 days is not available for animal feeding.

Table 2 - Dry matter production (kg/ha) and leaf/stem ratio (L/S) of Tifton 85 and their intercrops

\begin{tabular}{lcc}
\hline Intercrop & Dry matter production & L/S \\
\hline Single Tifton 85 & $3,206.04 * \mathrm{a}$ & $1.30 \mathrm{~b}$ \\
Tifton 85 (White oats) & $1,105.28 \mathrm{~b}$ & $1.43 \mathrm{~b}$ \\
Tifton 85 (Ryegrass) & $1,636.96 \mathrm{~b}$ & $1.48 \mathrm{~b}$ \\
White Oats (Tifton 85) & $1,467.68 \mathrm{~b}$ & $4.82 \mathrm{a}$ \\
Ryegrass (Tifton 85) & $1,026.08 \mathrm{~b}$ & $4.45 \mathrm{a}$ \\
CV & 9.04 & 13.31 \\
* Values followed by the same letter within column do not differ $(\mathrm{P}>0.05)$ from \\
\multicolumn{2}{l}{ each other by Tukey test. }
\end{tabular}

Nutritional value of hay is traditionally estimated by the concentration of crude protein, cell wall (NDF, ADF and lignin) and in vitro or in vivo digestibility (Paterson et al., 1994). The protein levels varied according to the cropping systems (Table 3 ) inasmuch as Tifton 85 has shown the lowest value (13.84\%) in cutting, differing $(\mathrm{P}<0.05)$ from intercroppings of Tifton $85+$ white oats and Tifton 85 + ryegrass with $19.01 \%$ of average values.

One hundred days after storage, Tifton 85 increased up to $10.97 \%$ CP, Tifton 85 + white oat intercrop did not change values and Tifton 85 + ryegrass intercrop increased up to 15.30 , decreasing down to 5\%. Floss et al (2007) obtained $17.9 \%$ CP for white oats at 56 days of development. The evaluation of potential availability of nitrogen compounds in feedstuff has received special attention under tropical conditions because of their high intercrop to organic matrix of plant cell wall. Such intercrop undertakes the accessibility of these compounds by ruminal microorganisms (Henriques et al. 2007).

The indigestible crude protein expresses the residue $\mathrm{CP}$ of dry matter digestibility and there was no difference $(\mathrm{P}>0.05)$ among non-tillage system and stages of hay production. The average was $6.61 \%$.

Table 3 - Chemical composition of Tifton 85 and intercropings with white oats and ryegrass before cutting, at baling time and 100 days after storage

\begin{tabular}{|c|c|c|c|c|c|c|}
\hline \multirow[t]{2}{*}{ Treatment } & \multicolumn{3}{|c|}{ Crude protein (\%) } & \multicolumn{3}{|c|}{ Indigestible crude protein (\%) } \\
\hline & Cut & Bailing & Storage & Cut & Bailing & Storage \\
\hline Tifton 85 & $13.84 \mathrm{bA} *$ & $14.20 \mathrm{bA}$ & $10.97 \mathrm{baA}$ & $6.12 \mathrm{aA}$ & $6.91 \mathrm{aA}$ & $5.58 \mathrm{aA}$ \\
\hline Tifton $85+$ Oat & $17.40 \mathrm{abA}$ & $19.640 \mathrm{aA}$ & $19.78 \mathrm{aA}$ & $6.18 \mathrm{aA}$ & $7.74 \mathrm{aA}$ & 5.33aA \\
\hline Tifton 85 + Ryegrass & 20.63aA & $19.20 \mathrm{aAB}$ & 15.30abB & 7.62aA & 7.60aA & $6.43 \mathrm{aA}$ \\
\hline \multirow[t]{2}{*}{$\mathrm{CV} \%$} & & 17.31 & & & 24.12 & \\
\hline & \multicolumn{3}{|c|}{ Neutral detergent insoluble protein ${ }^{1}(\%)$} & \multicolumn{3}{|c|}{ Acid detergent insoluble protein ${ }^{1}(\%$} \\
\hline Tifton 85 & $61.12 \mathrm{aA}$ & 59.13abA & $63.11 \mathrm{aA}$ & 32.13aA & $35.86 \mathrm{aA}$ & $32.30 \mathrm{aA}$ \\
\hline Tifton $85+$ Oat & $50.02 \mathrm{aA}$ & $48.64 \mathrm{bA}$ & $45.27 \mathrm{bA}$ & $22.09 \mathrm{aA}$ & $24.83 \mathrm{aA}$ & $26.95 \mathrm{aA}$ \\
\hline Tifton $85+$ Ryegrass & $67.27 \mathrm{aA}$ & $65.14 \mathrm{aA}$ & 57.50abA & $25.98 \mathrm{aA}$ & 26.98aA & $32.43 \mathrm{aA}$ \\
\hline \multirow[t]{2}{*}{$\mathrm{CV} \%$} & & 19.31 & & & 22.85 & \\
\hline & \multicolumn{3}{|c|}{ Neutral detergent fiber (\%) } & \multicolumn{3}{|c|}{ Acid detergent fiber (\%) } \\
\hline Tifton 85 & 77.77aA & 75.88aA & $78.22 \mathrm{aA}$ & 40.97aA & $37.50 \mathrm{aA}$ & $37.54 \mathrm{aA}$ \\
\hline Tifton $85+$ Oat & $68.89 \mathrm{bA}$ & $59.06 \mathrm{bB}$ & $72.82 \mathrm{aA}$ & $36.21 \mathrm{bAB}$ & $32.90 \mathrm{bB}$ & $38.14 \mathrm{aA}$ \\
\hline Tifton $85+$ Ryegrass & 74.06abA & $68.80 \mathrm{aA}$ & $73.03 \mathrm{aA}$ & $35.38 \mathrm{bAB}$ & $33.00 \mathrm{bB}$ & $37.23 \mathrm{aA}$ \\
\hline \multirow[t]{2}{*}{$\mathrm{CV} \%$} & & 6.54 & & & 6.58 & \\
\hline & \multicolumn{3}{|c|}{ Cellulose (\%) } & \multicolumn{3}{|c|}{ Hemicellulose (\%) } \\
\hline Tifton 85 & $28.03 \mathrm{aB}$ & $26.52 \mathrm{aB}$ & $30.25 \mathrm{aA}$ & $36.80 \mathrm{aA}$ & $38.38 \mathrm{aA}$ & $40.68 \mathrm{aA}$ \\
\hline Tifton $85+$ Oat & $25.35 \mathrm{bA}$ & $26.28 \mathrm{aA}$ & $26.54 \mathrm{bA}$ & $32.68 \mathrm{aAB}$ & $26.15 b B$ & $34.68 \mathrm{aA}$ \\
\hline Tifton $85+$ Ryegrass & $23.70 \mathrm{bB}$ & $24.83 \mathrm{aB}$ & $27.41 \mathrm{bA}$ & $38.67 \mathrm{aA}$ & $35.80 \mathrm{aA}$ & $35.80 \mathrm{aA}$ \\
\hline \multirow[t]{2}{*}{$\mathrm{CV} \%$} & 4.57 & 12.54 & & & & \\
\hline & \multicolumn{3}{|c|}{ Lignin (\%) } & \multicolumn{3}{|c|}{ Ash (\%) } \\
\hline Tifton 85 & $8.77 \mathrm{aA}$ & $7.62 \mathrm{aA}$ & $8.52 \mathrm{aA}$ & 7.13bA & $7.08 \mathrm{bA}$ & $6.81 \mathrm{bA}$ \\
\hline Tifton 85 + Oat & $6.94 \mathrm{aA}$ & 6.72abA & $4.89 \mathrm{bA}$ & $9.92 \mathrm{aA}$ & $9.05 \mathrm{aA}$ & $9.42 \mathrm{aA}$ \\
\hline Tifton 85 + Ryegrass & $9.49 \mathrm{aA}$ & $4.35 b B$ & $6.35 \mathrm{abB}$ & $7.26 \mathrm{bA}$ & $7.60 \mathrm{bA}$ & $7.98 \mathrm{bA}$ \\
\hline CV\% & \multicolumn{3}{|c|}{24.74} & \multicolumn{3}{|c|}{9.33} \\
\hline
\end{tabular}

*Means followed by lowercase letters within column and different capital letters within rows differ $(\mathrm{P}<0.05)$ from each other by Tukey test.

${ }^{1}$ Values expressed as \% crude protein. 


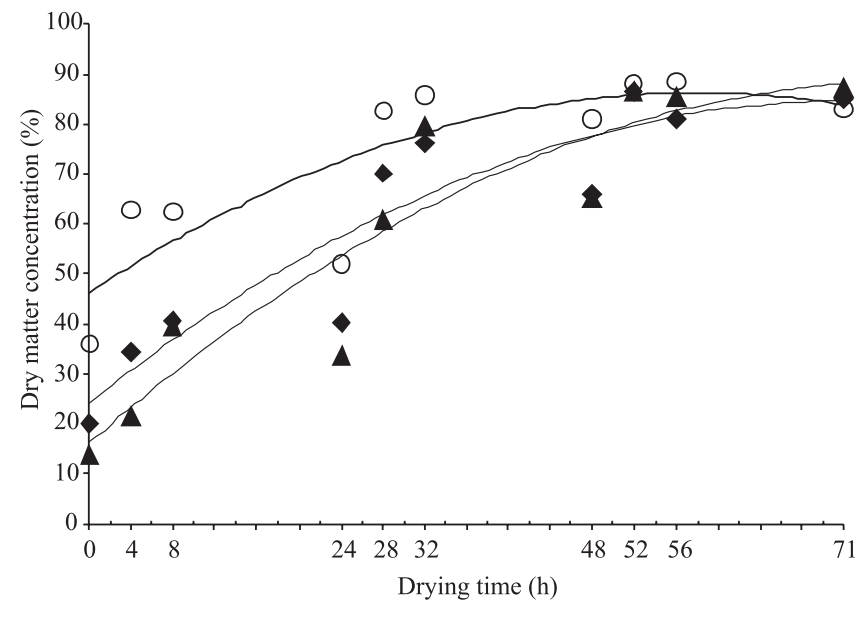

Figure 2 - Effect of drying time on the concentration of total dry matter in white oats hay (Tifton 85) $(\boldsymbol{\Delta}, \hat{Y}=16.214905$ $\left.+1.834703 \mathrm{x}-0.011610 \mathrm{X}^{2} ; \mathrm{R}^{2}=0.86\right)$, ryegrass hay (Tifton 85) (,$\hat{Y}=24.221964+1.660934 \mathrm{x}-0.011398$ $\left.\mathrm{X}^{2} ; \mathrm{R}^{2}=0.87\right)$ and single Tifton $85(\mathrm{O}, \hat{\mathrm{Y}}=46.290266$ $\left.+1.383683 \mathrm{x}-0.012002 \mathrm{X}^{2} ; \mathrm{R}^{2}=0.72\right)$.

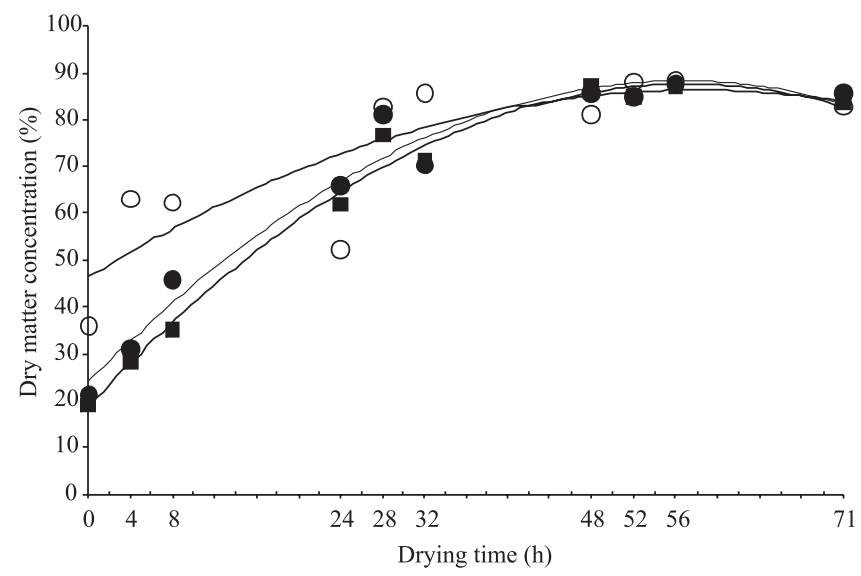

Figure 3 - Effect of drying time on the concentration of total dry matter in Tifton 85 hay + white oat $(\boldsymbol{\square}, \hat{\mathrm{Y}}=18.651618$ $\left.+2.425159 \mathrm{x}-0.021409 \mathrm{X}^{2} ; \mathrm{R}^{2}=0.99\right)$; Tifton $85+$ ryegrass $(\hat{Y}=23.988906+2.276133 x-0.020242$ $\left.\mathrm{X}^{2} ; \mathrm{R}^{2}=0.97\right)$ and single Tifton $85(\mathrm{O}, \hat{\mathrm{Y}}=46.290266$ $\left.+1.383683 \mathrm{x}-0.012002 \mathrm{X}^{2} ; \mathrm{R}^{2}=0.72\right)$

The neutral detergent insoluble protein varied according to the intercrop at baling time and after storage; the intercrop Tifton 85 + white oat presented lower NDIP percentage, followed by Tifton 85 + ryegrass intercrop which differed $(\mathrm{P}<0.05)$ from single Tifton 85 . Among the steps, NDIP percentages were constant, and Tifton $85+$ white oat showed lower percentage of neutral detergent insoluble protein. This indicated that there was less intercrop with the organic matrix of plant cell wall.

For acid detergent insoluble protein (ADIP), there was no difference $(\mathrm{P}>0.05)$ among intercrops and the stages. Tifton 85 + ryegrass showed slight increase after storage.
However, if the intercrops had been stored at high humidity levels, it would be expected increased levels of NDIP and ADIP due to Maillard reaction, which, according to Van Soest (1994), occurs when humidity is high, so temperature reaches values above $55^{\circ} \mathrm{C}$, inducing to non-enzymatic reactions among soluble carbohydrates and amine groups of amino acids with consequent reduction in protein digestibility.

ADIP may indicate a non-degradable nitrogen compounds fraction into rumen. However, recent studies that were carried out under tropical conditions showed complete absence of relationship among fraction of non-degradable nitrogen compounds into rumen environment and ADIP and the opportunity to be part of that last digestible item in guts (Detmann et al., 2004). Thus, the mere chemical association of ADIP as a predictor of a potential recovery of nitrogen compounds in feedstuff, especially those with high levels of cell wall components, could be considered questionable under tropical conditions (Detmann et al., 2004). It is suggested that ADIP should not be used as a predictor of non-degradable protein fraction, which should be estimated by biological methods, suggested by the protocols used to obtain NDIP levels (Clipes et al. 2006).

Fiber content is used as a negative index of diet quality as it represents the less digestible food fraction. However, fiber is required for functioning and normal metabolism of rumen; thus fiber quality becomes an important factor on diets for ruminants, mainly in dairy cows (Matos, 1989).

Content of neutral detergent fiber (Table 3) were lower for Tifton 85 + white oat and Tifton 85 + ryegrass intercrops; however, after storage, values did not differ $(\mathrm{P}>0.05)$ among cropping systems; but Tifton 85 presented $78.22 \%$ and the other treatments, $73.03 \%$ on average. Ferolla et al (2008) presented results of $57.82 \%$ NDF average levels for black oats under cutting at 45 days of resprout. Acid detergent fiber (Table 3 ) at the time of cutting and baling was the highest in Tifton 85, but, after storage, its responses were similar to other intercrops, so, its result was $37.67 \%$. Cecato et al (1998) recorded lower mean values for NDF and ADF with black oats at 56 days resprout with $49.5 \% \mathrm{NDF}$ and $27.8 \% \mathrm{ADF}$. Cellulose is the most important constituent of cell wall and its content can vary from 20 to $40 \%$ (Van Soest, 1994). Levels of cellulose were higher in Tifton 85 at cutting time and after storage (30\%); on the other hand, when the steps were compared, values increased in single Tifton 85 and Tifton 85 + ryegrass. Hemicellulose did not change after storage among crop systems, being nearly $37.05 \%$. Lignin is a constituent of cell wall that negatively influences degradation of tissues (Jung \& Engels, 2002, Lacerda et al., 2006). 
There was a reduction in lignin contents (Table 3) at baling and storage time, probably due to higher proportion of ryegrass in the samples. After storage, the single Tifton 85 had a higher ligninin content $(8.52 \%)$ and differed $(\mathrm{P}<0.05)$ from intercrops, so that its average was $5.62 \%$. Cecato et al. (1998) obtained 5.2\% lignin for black oats. The highest ash concentration was observed in Tifton $85+$ white oats intercrop with $9.46 \%$ average whereas for the other treatments, the average was around 7\% for single Tifton 85 and 7.61 for Tifton 85 + ryegrass intercrop. Ferolla et al. (2008) registered $10.45 \%$ ash for black oats under cutting conditions.

In vitro digestibility simulates digestion in the gastric tract of ruminants, therefore, estimating dry matter digestibility. Studies involving the most different hay species have consistently shown increases in consumption, with increases in digestibility values between $40-80 \%$ (Lyons et al. 1999). Dry matter in vitro digestibility at cutting time (Table 4) was the highest in Tifton 85 + white oats, so it differed $(\mathrm{P}<0.05)$ from Tifton 85 + ryegrass and from single Tifton 85 .

At baling time, digestibility was higher for Tifton $85+$ white oats and Tifton 85 + ryegrass with single Tifton 85 , therefore presenting $61.54 \%$ digestibility. One hundred days after storage, Tifton 85 + white oats showed 70.03\% digestibility whereas single Tifton showed the same value. This showed that intercrops had some drop in digestibility after storage. Floss et al. (2007) obtained 71\% IVDMD for white oat UPF7 at 56 days of development and recommend its use of 37 to 70 days after emergence; nevertheless Cecato et al. (1998) recorded 60.4\% IVDMD for black oats. Burton et al. (1993) obtained 60.3\% for values of in vitro digestibility of DM for Tifton 85 and Calixto Jr. et al. (2007) obtained 61.7\% IVDMD for Tifton 85 hay. Gonçales et al. (2003) registered $62 \%$ of IVDMD for Tifton 85 hay cut at 28 days of resprout. Such experimental results corroborate the results obtained in this research, which showed around $60 \%$ digestibility of Tifton 85 hay, but, when Tifton was associated with winter annual hays such as white oats and ryegrass, these values tended to be superior even with the reduction observed after storage.

Summer growth grasses present C4 photosynthetic cycle with more carbon sequestration, but, otherwise, this singularity causes anatomical changes and increases lignification of cell wall, resulting in decreased digestibility in relation to C3-metabolic cycle species (Moreira \& Reis, 2007).

In vitro $\mathrm{CP}$ digestibility (Table 4$)$ did not differ $(\mathrm{P}>0.05)$ among cropping systems, and stages presented $59.83 \%$ of mean value. Although IVCPD did not differ ( $>0.05$ ), it presented $62.11 \%$ of response after storage for Tifton $85+$ white oats intercrop. This restate contribution of white oats on improving hay quality produced in this period of the year. Calixto júnior et al. (2007) obtained 65.5\% IVCPD for Tifton 85 hay fertilized with $50 \mathrm{~kg} / \mathrm{ha}$ nitrogen during summer, whereas single Tifton 85 showed $53.37 \%$ values at the different stages of this experiment. This can be referred to several factors such as season, development period, climatic and soil conditions.

Table 4 - In vitro digestibility of DM and CP for Tifton 85 and intercrops with white oat and ryegrass before cutting at baling time and 100 days after storage

\begin{tabular}{|c|c|c|c|c|c|c|}
\hline \multirow[t]{2}{*}{ Treatment } & \multicolumn{3}{|c|}{ In vitro dry matter digestibility (\%) } & \multicolumn{3}{|c|}{ In vitro crude protein digestibility ${ }^{1}(\%)$} \\
\hline & Cutting & Bailing & Storage & Cutting & Bailing & Storage \\
\hline Tifton 85 & $60.39 \mathrm{cA}$ & $61.54 \mathrm{bA}$ & $61.12 \mathrm{bA}$ & $55.74 \mathrm{aA}$ & $51.15 \mathrm{aA}$ & $53.23 \mathrm{aA}$ \\
\hline Tifton 85 + white oats & $78.22 \mathrm{aA}$ & $81.40 \mathrm{aA}$ & $70.03 a \mathrm{~B}$ & $63.93 \mathrm{aA}$ & $60.16 \mathrm{aA}$ & $62.11 \mathrm{aA}$ \\
\hline $\begin{array}{l}\text { Tifton } 85 \text { + ryegrass } \\
\text { CV\% }\end{array}$ & $69.14 \mathrm{bAB}$ & $\begin{array}{c}70.28 \mathrm{aA} \\
6.85\end{array}$ & $67.27 \mathrm{abB}$ & $62.26 \mathrm{aA}$ & $\begin{array}{c}61.75 \mathrm{aA} \\
17.16\end{array}$ & $58.11 \mathrm{aA}$ \\
\hline
\end{tabular}

Means followed by lower case letters within the column and different capital letters within rows differ from each other by the Tukey test (P<0.05).

${ }^{1}$ Values expressed as \% of crude protein; $\mathrm{CV}=$ coefficient of variation.

\section{Conclusions}

Tifton 85 hay single produced features faster dehydration rate in the early drying stages. But, at the end of dehydration period, both single tifton 85 and intercrops with the winter annual grass reached dry matter contents at similar levels and were available for storage. Oversowing of white oats or ryegrass on areas of Tifton 85 hay production helps improving the nutritional value of the hay produced.

\section{References}

ANDRADE, M.V.M.; SILVA, D.S.; QUEIROZ FILHO, J.L. Desidratação de cultivares de alfalfa (Medicago sativa L.) duryng haymaking. Archivos Zootecnia, v.55, n.212, p.385-388, 2006.

ASSOCIATION OF OFFICIAL ANALYTICAL CHEMISTS - AOAC. Official methods of analysis. 15.ed. Virginia: Arlington, 1990. $1117 \mathrm{p}$.

BURTON, G.W., GATES, R.N.; HILL, G.M. Registration of "Tifton 85” bermudagrass. Crop Science, v.33, n.3, p.644-645, 1993. 
CALIXTO JÚNIOR, M.; JOBIM, C.C.; CANTO, M.W. Taxa de desidratação e composição químico-bromatológica do feno de grama-estrela (Cynodon nlemfuensis Vanderyst) em função de níveis de adubação nitrogenada. Semina: Ciências Agrárias, v.28, n.3, p.493-502, 2007.

CARNEVALLI, R.A.; SILVA, S.C.; CARVALHO, C.A.B. et al. Desempenho de ovinos e respostas de pastagens de Coastcross (Cynodon spp.) submetidas a regimes de desfolha sob lotação contínua. Pesquisa Agropecuária Brasileira, v.36, n.6, p.919-927, 2001

CECATO, U.; SARTI, L.L.; SAKAGUTI, E.S. et al. Avaliação de cultivares e linhagens de aveia (Avena spp.) Acta Scientiarum, v.20, n.3, p.347-354, 1998.

COLLINS, C.A. Hay preservation effects on yield and quality. In: MOORE, K.J.; KRAL, D.M.; VINEY, M.K. (Eds.). Post-harvest physiology and preservation of hays. Madison: American Society of Agronomy, 1995. p.67-90.

CLIPES, R.C.; DETEMANN, E.; SILVA, J.F.C. et al. Evaluation of acid detergent insolub protein as na estimator of rúmen nondegradable protein in tropical grass hays. Arquivo Brasileiro de Medicina Veterinária e Zootecnia, v.58, n.4, p.694-697, 2006.

DETMANN, E.; ZERVOUDAKIS, J.T.; CABRAL, L.S. et al. Validação de equações preditivas do potencial de degradação da fibra em detergente neutro em gramíneas tropicais. Revista Brasileira de Zootecnia, v.33, n.6, p.1866-1875, 2004.

FEROLLA, F.S., VÁSQUES, H.M, SILVA, J.F.C. et al. Composição bromatológica e fracionamento de carboidratos e proteínas de aveia-preta e triticale sob corte e pastejo. Revista Brasileira da Zootecnia, v.37, n.2, p.343-349, 2008.

FLOSS, E.L.; PALHANO, A.L.; SOARES FILHO, C.V. et al. Crescimento, produtividade, caracterização e composição química da aveia branca. Acta Scientiarum.Animal Science, v.29, n.1, p.1-7, 2007.

FREITAS, F.K.; ROCHA, M.G.; BRONDANI, I.L. et al. Suplementação energética na recria de fêmeas de corte em pastagem cultivada de inverno. Dinâmica da pastagem. Revista Brasileira de Zootecnia, v.34, n.6, p.2029-2038, 2005.

GONÇALVES, G.D.; SANTOS, G.T.; JOBIM, C.C. et al. Determinação do consumo, da digestibilidade e das frações protéicas e de carboidratos do feno de Tifton 85 em diferentes idades de corte. Revista Brasileira de Zootecnia, v.32, n.4, p.804-813, 2003.

HENRIQUES, L.T.; VASQUES, H.M.; PEREIRA, O. Frações dos compostos nitroggenados associados à parede celular em forragens tropicais. Arquivos Brasileiros de Medicina Veterinária e Zootecnia, v.59, n.1, p.258-263, 2007.

HOLDEN, L.A. Comparasion of methods of in vitro matter digestibility for ten feeds. Journal Dairy Science, v.2, n.8, p.1791-1794, 1999.

INSTITUTO AGRONÔMICO DO PARANÁ - IAPAR. Cartas climáticas do Paraná. [2006]. Available at: <http://200.201.27.14/ Site/Sma/Cartas_Climaticas/Classificação_Climaticas.htm>. Accessed on: Sept. 3, 2008.
JUNG, H.G.; ENGELS, F.M. Alfalfa stem tissues: cell, wall deposition, composition and degradability. Crop Science, v.24, n.2, p.524-534, 2002.

LACERDA, R.S.; GOMIDE, C.A.; FUKUSHIMA, R.S.; HERLING, V.R. Lignin concentration in oat (Avena byzantina L.) aerial part as mensured by four analytical methods. Brazilian Journal Veterinary Reserch: Animal Science, v.43, n.3, p.400-407, 2006.

LYONS, R.K.; MACHEN, R.; FORBES, T.D.A. [1999] Undertanding hay intake in range animals. Texas Agricultural Extension Service, p.6. Available at: <http:// wildlife.tamu.edu/publications/L5152>. Pdf. Accessed on: Mar 5, 2009.

MATOS, L.L. Utilização de fibra pelos ruminantes. In: MINI SIMPÓSIO DO COLÉGIO BRASILEIRO DE NUTRIÇÃO ANIMAL, 2., 1989, Campinas. Anais... Campinas: CBNA, 1989. p.91.

MERTENS, D.R. Regulation of hay intake. In: FAHEY JUNIOR, G.R. (Ed.) Hay quality, evaluation and utilization. Madison: American Society of Agronomy, 1994. p.450-493.

MOREIRA, A.L.; REIS, R.A. Técnica da sobressemeadura de forrageiras de inverno sobre o capim Tifton-85. Boletim de Indústria Animal, v.64, n.3, p.197-206, 2007.

MOSER, L.E. Post-harvest physiological changes in hay plants. In: MOORE, K.J.; KRAL, D.M.; VINEY, M.K. (Eds.). Postharvest physiology and preservation of hays. Madison: American Society of Agronomy, 1995. p.1-19.

MUCK, R.E.; SHINNERS, K.J. Conserved hays (silage and hay): Progress and Priorities. In: INTERNATIONAL GRASSLAND CONGRESS, 29., 2001, São Pedro. Proceedings... Piracicaba: Brazilian Society of animal Husbandry, 2001. p.753-763.

PATERSON, J.A.; BELEYA, R.L.; BOWMAN, J.P. et al. The impact of hay quality and supplementation regimsn on ruminant animal intake and performance. In: FAHEY JUNIOR, G.C. (Ed.). Hay quality, evaluation, and utilization. Madison: American Society of Agronomy; Crop Science Society of America, 1994. p.59-114.

ROTZ, C.A. Field curing of hay. In: MOORE, K.J.; KRAL, D.M.; VINEY, M.K. (Eds). Post-harvest physiology and preservation of hays. Madison: American Society of Agronomy, 1995. p.39-66.

UNIVERSIDADE FEDERAL DE VIÇOSA - UFV. SAEG - Sistema para análises estatísticas e genética; versão 7.0. Viçosa, MG: Fundação Arthur Bernardes, 1997.

SILVA, D.J.; QUEIROZ, A.C. Análise de alimentos: métodos químicos e biológicos. Viçosa, MG: UFV, 2006. 235p.

TILLEY, J.M.A.; TERRY, R.A. A two stagee technique for the in vitro digestion of hay crops. Joumal of the British Grassiand Society, v.18, n.2, p.104-111, 1963.

VAN SOEST, P.J.; ROBERTSON, J.B.; LEWIS, B.A. Methods for dietary fiber, neutral detergent fiber and non starch polysaccharides in relation to animal nutrition. Journal of Dairy Science, n.74, p.3583-3597, 1991.

VAN SOEST, P.J. Nutritional ecology of the ruminant. Ithaca: Constock Publishing Associates, 1994. 476p. 